\title{
Effect of Ascorbic acid on the wilting and resistance of Capsicum annum L. Plant
}

\author{
Sajjad Ali ${ }^{*}$, Kashif $\mathrm{Ali}^{2}$, Ehsan $\mathrm{Ali}^{3}$, Syed Salim Shah ${ }^{4}$, Muhammad \\ Saleem Khan ${ }^{2}$, Muhammad Ali ${ }^{5}$, Ikramullah ${ }^{4}$ and Wisal Muhammad \\ $\mathrm{Khan}^{2}$ \\ 1. Department of Botany, Bacha khan University Charsadda, Pakistan \\ 2. Department of Botany, Islamia College Peshawar, Pakistan \\ 3. Department of Plant Sciences, University of Wuhan, China \\ 4. Department of Plant Breeding and Genetics, Bacha khan University Charsadda, Pakistan \\ 5. Department of Biotechnology, Bacha khan University Charsadda, Pakistan \\ *Corresponding author's email: sajjad_ali00@yahoo.com
}

Citation

Sajjad Ali, Kashif Ali, Ehsan Ali, Syed Salim Shah, Muhammad Saleem Khan, Muhammad Ali, Ikramullah and Wisal Muhammad Khan. Effect of Ascorbic acid on the wilting and resistance of Capsicum annum L. Plant. Pure and Applied Biology. Vol. 5, Issue 1, 2016, pp172-176. http://dx.doi.org/10.19045/bspab.2016.50022

\begin{tabular}{llll}
\hline \hline Received: 03/11/2015 & Revised: 12/01/2016 & Accepted: 25/01/2016 & Online First: 01/02/2016 \\
\hline \hline
\end{tabular}

\section{Abstract}

The change occurred in pepper plant are able to reversed from permanent welting in entire red pepper (Capsicum annum) followed by a very harsh salt stress of root exposure to $200 \mathrm{mM}$ solution of Sodium chloride. It was noticed that a seed or seedling present in saline soil was wilted very quickly, but if replaced to non-saline soil within 6 hours then seed start recovery however if the duration is increase and it reaches to 9 hour, then the salt stress make it plastic i-e remained wilt and died but the submission of antioxidant $(0.5 \mathrm{mM}$ ascorbic acid) to the medium of root during at the time when the plant is in salt stress condition, it recover the stress almost $50 \%$ of wilted seedling others solution which containing organic solution they does not effective like antioxidants (vitamin C), The salt severely damage the root, stem and leaves by accumulation in them.

Key words: Red paper; Sodium chloride; Antioxidants

\section{Introduction}

Negative plant response to concentration of salt in a solution effect the plant and also on condition as well as the duration of the particular stress the plants strain (response to salt stress, is variable from stopping nature growth and progressing faster leaf ageing under a normal pressure. while in severe stress permanent welting of shoot occur the process underlying these variable reaction to comparable effect to salinity are still far from clear [1]. This report investigate that fast change from reversible to permanent wilting in Capsicum annum seedling when face to huge level of Sodium chloride solution. One condition was that salinity changed cellular storage of injurious active $\mathrm{O}_{2}$ species might be associated as we know about per oxidation that free oxygen can damage the lipids protein, DNA that why the active oxygen species can injure essential necessary lipid as well protein and DNA [2, 3]. Level Active oxygen which is present in plants, when the condition is normal and suitable for growth, than the plant produce antioxidant which prevent the work of 
antioxidant and that is called protective antioxidants. However when the condition is not suitable the proactivity antioxidants become low and doesn't stop the peroxidation [4]. There may be antioxidation enzyme have been reported.

Their report also fallows another technique which would be to larger the comparative level of cellular enzyme substrate and that is vitamin $C$ (ascorbic acid). As we know that vitamin is water soluble so if we give the vitamin $\mathrm{C}$ from the outer source, so that act as fundamental substrate in the cyclic pathway for enzyme detoxification of hydrogen per oxide, by the addition of this it act directly to neutralize nascent oxygen (atomic $\mathrm{O}_{2}$ which is highly reactive)

This report investigate the following facts.

A. A red pepper seedling face permanent wilting when it grow in salt stress area or soil and is joined with salt increase in cellular level of destruction active oxygen species.

B. Whenever we add ascorbic acid (vitamin c) which is additional to the root of seedling, so it decreases the buildup of active oxygen which decreases the peroxidation. So the role of ascorbic acid is so important.

\section{Materials and methods}

\section{Plant progress}

Red pepper seed were germinated in without light for 2days and then for their growth the polyslevene remain above surface with the root held in supplied or infused with oxygen 0.1 straight modified hog land solution plus $\mathrm{MCaCl}_{2}$ for the purpose to maintain the activity and work of calcium at adequate level. The chamber i-e growth chamber was at $27 \pm 2 \mathrm{C}^{0}$ with $12 \mathrm{hrs}$ a day and $150 \mu \mathrm{mol}$ $\mathrm{S}^{-1} \mathrm{M}^{-2}$ light (power intensity). The amount of water vapor in air is also variable during days and night as well as i.e. at the day $45 \%$ and at night $65 \%$.

\section{The survival of seedling}

Before treatment of salt 12-16 uniformed seedling were placed in incubator also with their root in 4.01 of nutrient minerals solution contain different nutrients probability with the adding of recently prepared $0.6 \mathrm{mM}$ ascorbic acid for $22 \mathrm{hr}$ when this duration is wind up then the seedling were again move to fresh nutrients solution $\pm 200 \mathrm{mM}$ Sodium chloride \pm 0.3 $\mathrm{mm}$ Ascorbic acid. Sodium chloride at 200 $\mathrm{mm}$ rapidly changed completely wilting of shoot. Where the solution of poly ethylene glycol (PEG) is also used to activate the osmotic effect of $200 \mathrm{mM}$ Sodium chloride.

Ascorbic acid

Vitamin $C$ the outcome of external supply on the tissue organization of Ascorbic acid was determined. The seedling which is germinated were incubated with or without $0.6 \mathrm{mM}$ for $22 \mathrm{hrs}$ and then by the additional $9 \mathrm{hrs}$ with or the absence of $200 \mathrm{mM}$ sodium chloride. After rising $0.6 \mathrm{mM} \mathrm{\textrm {CaCl } _ { 2 }}$ stem leaves and root they are freezed by liquid nitrogen and ground mortor ground tissue then tainted with $9 \mathrm{ml}$ of $9 \%$ TCA and when the supernatant gain after centrifugation in $1600 \mathrm{gm}$ for $13-16 \mathrm{~mm}$ at $3 \mathrm{c}$ was analyzed ( according to Walk \& McKenzie 1993).

\section{Peroxidation of lipids}

The compression rate of lipids were tested by determine the level of malondialdehyde in $2 \mathrm{gm}$ of leaf, root and stem. The product of lipids peroxidation is malondialdehyde which was then examine by thiobarbitraic acid. When the extra Ascorbic acid or sodium chloride is add to the extracted medium so when this is add did not affect the measurement without addition of reactive TBA. Three separate experiment which include 8 or more plant per treatment result for root stem a leaves in each mean.

\section{Accumulation of Sodium}

The effect of Ascorbic acid which is possible on the accumulation of sodium in the stem of salinized seedling. intact seedling were raised $0.6 \mathrm{mM} \mathrm{CaCl} 2$ and $3 \mathrm{~cm}$ is exiced from the starting point of the stem when anhydrous by oven for $68 \mathrm{hrs}$ at $71 \mathrm{C}^{0}$ 
the powder weighted and incubate in $8 \mathrm{ml}$ 0.3 Sodium chloride for $44 \mathrm{hrs}$, the filtrating and determination of contents of ion by ICP test.

\section{Results}

The ascorbic acid larger the ability of seeding to get back from salt pressure. Root when expose to intense salt pressure (200 $\mathrm{mM}$ sodium chloride) and that cause quick and complete flaccid with the apparent fall down of stem and leaves, resisting was tested by determine the repossession of wilted red pepper seedling when it transfer to non-saline medium the repossession was notice in sixty mints, but the seedling show recovery because that was placed for $6 \mathrm{hrs}$ or $5 \mathrm{hrs}$ with saline to non-saline environmental.

However when the seed is placed in saline medium for longer time i.e. ( 8 to $9 \mathrm{hrs}$.) resulted will be in advanced decrease in repossession thus after $9 \mathrm{hrs}$. Seedling stay wilted and afterward died (zero\% surviving) despite the transfer back to non-saline condition. If we make the distinguish between osmotic and toxic effect the seedling treatment to similar using a nonpenetrating polyethylene glycole alternative of sodium chloride. Treatment of the seedling with polyethylene glycol and contrast to the sodium chloride. Seedling to which we provided polyethylene glycol solution at $1.35 \mathrm{mpa}$ osmotic potential wills completely wilted. Almost all the addition of ascorbic acid (vitamin C) to the root increase the capacity of survival treated with
$200 \mathrm{mM}$ sodium chloride for 7,8,9 hrs. Thus seedling treate for $9 \mathrm{hrs}$. With $200 \mathrm{mM}$ Sodium chloride alone doesn't showed any fruitful result and $0 \%$ of regain however c.50\% of seedling treated for $9 \mathrm{hrs}$. With $200 \mathrm{mM}$ Sodium chloride and $0.4 \mathrm{mM}$ of ascorbic acid by the mixture of these showed repaired recovery after return to non-saline medium. Chemically analysis shown that root additing of ascorbic acid $(0.4 \mathrm{mM})$ for $33 \mathrm{hrs}(24+9 \mathrm{hrs})$ increase seedling level from $2.4 \pm 0.2 \mu \mathrm{mmol} \mathrm{g}^{-1} \mathrm{FW}$ to $3.1 \pm 0.3 \mu \mathrm{mol} \mathrm{g}^{-1} \mathrm{FW}$ in salinized seedling and form $2.3 \pm 0.2 \mu \mathrm{mol} \mathrm{g}{ }^{-1} \mathrm{FW}$ to $2.3 \pm 0.2 \mu \mathrm{mol} \mathrm{g}{ }^{-1} \mathrm{FW}$ to $3.1 \pm 0.2 \mu \mathrm{mol} \mathrm{g}^{-1}$ FW in non-saline seedling. So we make a comparison on the serving outcome of ascorbic acid on the survival and that of small organic compound with no know antioxidant activate when we add glucose, glycine, beatine, leucine or proline to root every at $0.4 \mathrm{mM}$ have very low and sometime without any out come on seedling surviving of $200 \mathrm{mM}$ Sodium chloride treatment for $9 \mathrm{hrs}$. So the addition of ascorbic acid makes it,s survival complete.

One of the anticipated result of pressure changed celluler form of active oxygen species high the peroxidation. The assay of celluler increment of lipids per-oxidation products if we provide thiobarbituric acid reactive substance (TBARS). Salt stress change progressive increase in accumulation of TABRAS in root, stem, and leave of salt stressed seedling as 6n, 9n.

Table 1. Effect of Ascorbic acid on different parts of a plant

\begin{tabular}{|l|l|l|l|l|}
\hline Treatment & \multicolumn{3}{|c|}{ TBRAS $(\boldsymbol{\mu m o l ~ g - 1 ~ F W ) ~}$} \\
\hline & $\begin{array}{l}\text { 1 h Sodium } \\
\text { chloride }\end{array}$ & $\begin{array}{l}\mathbf{1} \text { h } \\
\text { Sodium } \\
\text { chloride }\end{array}$ & \\
\hline Root & $555 \pm 60$ & Root & $555 \pm 60$ & Root \\
\hline Root+Ascorbic acid & $385 \pm 5$ & Root+Ascorbic acid & $385 \pm 5$ & Root+Ascorbic acid \\
\hline Stem & $200 \pm 17$ & Stem & $200 \pm 17$ & Stem \\
\hline Stem+Ascorbic acid & $212 \pm 21$ & $316 \pm 35$ & $465+13$ & Stem+Ascorbic acid \\
\hline Leaf & $360 \pm 18$ & $560 \pm 20$ & $846+15$ & Leaf \\
\hline Leaf+Ascorbic acid & $365 \pm 15$ & $424 \pm 13$ & $547+22$ & Leaf+Ascorbic acid \\
\hline
\end{tabular}




\section{Discussion}

The wilted Red Pepper (Capsicum anum) seedling showed an awesome ability for shoot regain up to $6 \mathrm{n}$ of intense salt stress treating with $200 \mathrm{Mm}$ Sodium chloride. However Green way et al 1980 observe a same abilty for shoot recovery in Red pepper plant (seedlings) in a day one or more cycle daily cycle of wilting by Air drying for half an hour and then back the root to aqueous media [5], But the loss of the ability to recover from salt stress and change to permanent wilting, does not appear. The results show transparency that complete and permanent wilting of $100 \%$ of the seedling change by the $9 \mathrm{~h}$ of salt treatment has relation to uptake and toxicity of Sodium chloride but a suitable treatment of seedling for $9 \mathrm{~h}$ with a solution of nonpenetrating PEG 500 in place of Sodium chloride did not change permanent wilting. The external supply of Ascorbic acid (vitamin c) help in increase tissue and cell growth levels in Red pepper seedling. As show in the previous report showing plant uptake of external ascorbic acid [6]. The ascorbic acid (vitamin c) addition increased the percentage of seedling of Capsicum annum able to survive the toxic effect of a $9 \mathrm{~h}$ expose to Sodium chloride. With this if we use organic carbon sources without direct antioxidants activity. The remarkable protective effect of external ascorbic acid is appeared like its antioxidants activity.

Several result show that the salt induced transition to permanent wilting. A few attempts indicate that the salt induced transition to complete wilting occurs in plants were related with enhance in the cellular activity of damaging active oxygen species (AOS). AOS and the effect of ascorbic acid on the seedling survival were associated with partial inhibition of these increases.
A) The level of TBARS in leaf, root, stem and these parameters which show in the experiment, their tissue increased also their development increase when the plant is in stress condition.

B) Providing external ascorbic acid is constantly change and almost smaller salt induced collection of TBARS and also reduces the seedling death because the TBARS also reduced stress at some suitable level.

When the TBARS is accumulated in roots, stem, leaves and other effected part of the plant which is salinized treated with stopping growth effect of ascorbic acid was appear after $6 \mathrm{~h}$ of Sodium chloride treatment. All the suffer seedling have the capacity for rapid recovery i-e that tissue which is treated with the additional ascorbic acid is still alive. Although the stopping growth and change in growth outcome of ascorbic acid on lipid breakdown and larger seedling existence visible to be related. But the real circumstances is not clear know one condition was that supplemental ascorbic acid would stop stress change increase in the leaking of important electrolyte follow that injure which is caused by peroxidation [7]. However the ascorbic acid which on add or introduced not stop or increase the leakage of electrolyte from the root of that Red pepper plant, which is salt effected, and also do not help in accumulation of Sodium chloride in the different parts. Finally the face is that leaves and roots were produced by the seedling which have got recovery from $9 \mathrm{hr}$ of salt treating with ascorbic acid which is suppose that the ascorbic acid which is add may effect that tissue which have the ability of cell division in the salt pressure root and shoot tissue, while the small ascorbic acid may have been touch with mitotic inactive in the root dividing cell and reversed treatment of with external ascorbic acid was touch with an larger shape 
$33 \%-53 \%$ in the normal root and shoot emergence from somatic embryo [8-11]. So the above report show that root treated with the ascorbic acid which was external can larger the ability of red pepper plant to alive under very harsh condition i.e. when the plant is kept $9 \mathrm{hr}$ in the salt stress which almost lethal for that the plant increase its resistance capacity is associated with antioxidant activity of ascorbic acid.

Authors' contributions

Conceived and designed the experiments: E Ali \& S Ali, Performed the experiments: E Ali \& SS Shah, Analyzed the data: I Ullah \& M Ali, Wrote the paper: Kali, S Ali \& WM Khan

\section{References}

1. Arrigoni O, Calabrese G, De Gara L, Bitonti MB \& Liso R (1997). Correlation between changes in cell ascorbate and growth of Lupinus albus seedlings. $J$ of Plant Physiology 150(3): 302-308.

2. Blokhina O, Virolainen E \& Fagerstedt KV (2003). Antioxidants, oxidative damage and oxygen deprivation stress: a review. Annals of botany 91(2): 179-194.

3. Floyd RA (1990). Role of oxygen free radicals in carcinogenesis and brain ischemia. The FASEB $j$ 4(9), 2587-2597.

4. Francois LE \& Maas, EV (1994). Crop response and management on salt- affected soils. Handbook of plant and crop stress, 149-181.

5. Greenway H \& Munns R (1980). Mechanisms of salt tolerance in nonhalophytes. Annual review of plant physiology, 31(1), 149-190.

6. Grieve CM \& Maas EV (1984). Betaine accumulation in salt-stressed sorghum. Physiologia Plantarum 61(2), 167-171.

7. Pacifici RE \& Davies KJA (1991). Protein, lipid and DNA repair systems in oxidative stress: the free-radical theory of aging revisited. Gerontology, 37(1-3), 166-180.

8. Park G (2001) (Ed.). Anti-Ageing and Skincare Made Easy: Radiance with Confidence. SmarteBookShop.

9. Peterson MGE, Kovar-Toledano PA, Otis JC, Allegrante JP, Mackenzie CR, Gutin B \& Kroll MA (1993). Effect of a walking program on gait characteristics in patients with osteoarthritis. Arthritis \& Rheumatism 6(1), 11-16.

10. Sinatra ST (2000). Heartsense for Women: Your Plan for Natural Prevention and Treatment. Regnery Publishing.

11. Tonic EUAAG (2000). william e. court. Ginseng: the genus Panax, 121. 